\title{
ONLINE TRAVEL AGENCY MARKETING STRATEGY: IMPLICATIONS FOR CONSUMER REPURCHASE DECISION
}

\author{
Syafrida Hafni Sahir \\ syahaf@yahool.com \\ Universitas Medan Area \\ Suginam \\ Universitas Budi Darma \\ Mochammad Fahlevi \\ Universitas Bina Nusantara
}

\begin{abstract}
ABSTRAK
OTA dan konsumsi masyarakat atas transaksi layanan online di Indonesia terus tumbuh. Pemasaran online paling banyak dilakukan oleh perusahaan perjalanan online untuk menarik pelanggan dan meningkatkan loyalitas pelanggan yang diantisipasi. Persaingan perjalanan online menjadi semakin ketat. Sehingga konsumen akan terus melakukan transaksi travel online kembali. Studi ini mengeksplorasi travel online yang signifikan di Indonesia yaitu Traveloka, penelitian ini menggunakan pendekatan kuantitatif dengan memanfaatkan data dari 100 responden dan menggunakan alat perangkat lunak Partial Least Square untuk menganalisa model. Temuan penelitian ini menjelaskan bahwa promosi pemasaran online berpengaruh signifikan terhadap pembelian Kembali, serta kepuasan pelanggan berhasil memediasi antara promosi pemasaran online terhadap pembelian kembali. Hasil ini memberikan bukti bahwa promosi pemasaran online sangat penting bagi pemasaran dan pertumbuhan bisnis perusahaan online seperti Traveloka. Selain itu, penting untuk mempertimbangkan kepuasan pelanggan sebagai variabel intervening baik secara langsung maupun sebagai variabel mediasi antara promosi pemasaran online dan pengambilan keputusan pembelian kembali memiliki pengaruh yang besar terhadap pembelian kembali konsumen. Nilai $R$ square yang begitu tinggi antara hubungan antar variabel baik secara langsung maupun tidak langsung memberikan informasi bahwa kedua variabel tersebut mempengaruhi variabel keputusan pembelian kembali cukup besar sehingga pengusaha travel online khususnya Traveloka yang menjadi fokus penelitian ini perlu pertimbangkan permasalahan ini.
\end{abstract}

Kata kunci: OTA, pemasaran, strategi, kepuasan, pembelian kembali.

\section{ABSTRACT}

OTA and public consumption for online service transactions in Indonesia continues to grow. Online marketing is mostly done by online travel companies to attract customers and increase anticipated customer loyalty. The competition for online travel is becoming increasingly fierce. So that consumer will continue to make travel transactions online again. This study explores the significant online travel in Indonesia, namely Traveloka. This study uses a quantitative approach by utilizing data from 100 respondents and using the Partial Least Square software tool to analyze the model. The findings of this study explain that online marketing promotions have a significant effect on repurchase, and customer satisfaction has successfully mediated between online marketing promotions and repurchases. These results provide evidence that online marketing promotion is very important for the marketing and business growth of online companies such as Traveloka. In addition, it is important to consider customer satisfaction as an intervening variable both directly and as a mediating variable between online marketing promotion and repurchase decision making which has a major influence on consumer repurchase. The high $R$ square value between the relationship between variables, both directly and indirectly, provides information that these two variables influence the repurchase decision variable, so that online travel entrepreneurs, especially Traveloka, who are the focus of this research, need to consider this problem. 
Key words: OTA, marketing, strategy, satisfaction, repurchase decision.

\section{INTRODUCTION}

Over the years, the advent of ecommerce transactions in Indonesia has seen growth, allowing the online tourism sector to gain the ultimate profit and become one of Indonesia's leading drivers of ecommerce. Competitions between manufacturers to win the market have become more severe with the advancement of current technology. Therefore, knowing the purpose of consumer purchasing has become a key factor in establishing the product's competitive advantages to remain competitive and succeed during fierce competition. In addition, consumer behavior analysis is an important element in understanding how a customer responds to the introduction of new goods and enhancing the likelihood of buying the product.

The need to create online websites that can offer outstanding online experiences has become the key challenges for online travel agents in Indonesia, mainly attracting more visitors to their website, winning competitions and generating more sales, the primary factor that affects the intention of customers to purchase, the enjoyment of online shopping and customer satisfaction.

The Internet is one of the information and communication technologies that is developing very rapidly and will make it easier for humans to do activities. Therefore, many marketers use the internet as a platform for communicating information from companies to the public to attract customers (Supriadi et al., 2020).

In the Indonesian start-up world, one of the superior and fast-growing companies is the travel services company. Online Travel Agencies (OTA) operations are commonly used and sought after as a branch of commerce. A February 2018 survey conducted by Jakpat (2016) Mobile Survey Platform tests the consumption habits of Indonesian customers To OTA equipment. Findings from this study indicate that in the past six months, 71.44 percent of respon- dents have used OTA services for ticket or hotel booking requirements. Other findings also revealed that $83.95 \%$ of all respondents used smartphones to access OTA services. By means of bank account transfers / ATM, as many as 69.26 percent of respondents make payments to OTA services (Gao and Bai, 2014).

In Indonesia, the traditional travel business has faded, nearly $60 \%$ of transportation ticket bookings and hotels have used online booking through OTAs, such as traveloka, tiket.com, and booking.com (Adiyanto and Subakti, 2018). Recent developments, the existence of OTA which increasingly shows the positive impact of the internet in the tourism industry sector. OTA is a form of internet application that makes it easy for teenage consumers to travel by directly choosing the accommodation and transportation to be used without going through long intermediary routes. The role of the internet has made OTA a more effective distribution channel than traditional travel agents (Adiyanto and Subakti, 2018).

Marketing research in the tourism and hospitality sector places a lot of emphasis on the use of internet technology to replace traditional marketing tools and encourage more competitive marketing practices.

E-commerce is a meeting place for sellers and buyers or producers and consumers who want to make transactions online via the internet network (Suwarni et al., 2020). The development of the internet and digital is very fast in the era of globalization which has led to the formation of a new business world, where everyone has the ability to communicate with others without any restrictions (Sutia et al., 2020). At this time consumers can easily buy and sell transacttions online. The era of globalization demands fast and easy services and services. In this era, E-commerce began to emerge which is useful as a liaison between consumers and producers, where in E-commerce 
sellers and buyers can make buying and selling transactions through internet services and make online payments via mobile banking (Suwarni et al., 2020). Today's banking services have undergone many changes with technological advances. Banking in Indonesia is trying to keep up with fintech that has emerged quite advanced in Indonesia so that it is taking the role of banking for longer (Kasbuntoro et al., 2020).

The internet is used for a variety of reasons, including as a source of information, communication methods, market media, and social systems (Juhandi et al., 2020). In fact the Internet has become a channel for marketers so that more and more business people see marketing via the Internet as indispensable in order to remain competitive in the modern global economy. Information will have great meaning if it can be conveyed quickly and accurately. Because it is able to increase the rapid progress of business through online. This raises a thought among businesspeople to make an innovation to create a start-up company so that it can be accessed or enjoyed by the wider community.

Because there are business opportunities that are deployed in the world of tourism with the support of many tours in Indonesia, this is supported by the many cultures that are presented in Indonesia that are able to attract foreign or domestic tourists to explore the archipelago. Many travel agents provide airline ticket purchase services with various routes online through a website.

In terms of meeting information needs, each consumer has a different level of satisfaction with the existing media and people's consumptive behavior by using the online service media used from Traveloka. Kotler argues that, "satisfaction is using the level of a person's feelings after comparing the performance or results he feels compared to his expectations." Meanwhile, according to Adila et al., (2020) consumer satisfaction is a label used by consumers to summarize a set of actions or actions. Seen, related to a product or service.

The hotel industry is one of the mainstay sectors of the government today that wants to focus on building tourism in Indonesia which provides a sizable state revenue of $\$ 17.6$ billion (Kemenparekraf, 2020). Today hospitality is one of the fastest growing sectors in the world in the economy. The tourism industry has a role for a country's economy because it generates foreign exchange, absorbs labor, and adds income to tourist areas (Badan Pusat Statistik, 2018).

The tourism industry can introduce Indonesia to the international community because Indonesia's natural wealth, cultural uniqueness, and natural beauty will attract foreign tourists to visit Indonesia. The increase in the tourism industry must be accompanied by good services and facilities that are owned by Indonesia. In research conducted by the Trip Advisor Index on several major hotels in the world, Indonesia has the best and most profitable business prospects in the world in 2012 for the hotel business (Adiyanto and Subakti, 2018). Good hotel services and provision are urgently needed by Indonesia because Indonesia's growing tourism industry requires a maximum level of service to keep attracting foreign tourists visiting Indonesia.

Good services must be adjusted to the availability of hotels, hotel rooms and other accommodations as well as skilled workforce in the tourism industry services. Many developing countries cannot maximize the tourism industry in their country, so the availability of minimal facilities will reduce the desire of visitors to travel to that country.

The increase in a number of non-hotel inns in the last two years was recorded at approximately 28,000 businesses and total rooms reaching 700,000 . In this data, especially in the star hotel class, it is still dominated by 3 star hotels, which is 39\% of the total star hotels in Indonesia (Badan Pusat Statistik, 2018). 
Traveling is currently becoming a new necessity for the general public. Visiting a new destination in a certain area just for traveling or doing business in another area becomes a reason for someone to travel. The necessities of life for Indonesians are no longer about food, clothing and shelter. Indonesian people choose traveling as their second priority after saving money (Fahlevi et al., 2020).

Shopping online in recent years has become a new way made by marketers to make it easier for their consumers. It is easy for consumers who are superior in making online purchases, successfully attracting modern consumers to shop online, because these purchases can be made anywhere and anytime as long as they are still there is an internet connection and practical in use (Fahlevi et al., 2019).

In Indonesia, currently shopping online has experienced rapid growth. About half of Indonesian consumers plan to buy flight tickets online $(55 \%)$ and book hotels and travel agencies (46\%) for the next six months. Four in ten consumers $(40 \%)$ plan to buy an e-book (ebook), nearly four in ten consumers plan to buy clothes/accessories /shoes $(37 \%)$, and more than a third of consumers plan to purchase event tickets $(34 \%)$ online (Wicaksono and Seminari, 2016). Researchers estimate that this comes from advertisements made by marketers regarding the ease of online shopping.

It is not enough for a product in a brand to only be concerned with operational/ technical matters. Marketers need to pay attention to non-operational/technical mat-ters. The non-technical thing that marketers need to pay attention to in selling their products is promotion (Rabiah et al., 2020).

Research on online travel agencies in Indonesia is still very minimal, especially those related to online marketing promotion, this study seeks to explain online marketing promotion and the role of customer satisfaction because in several previous studies many have explained that online marketing promotion will be less successful if it is not accompanied by customer satisfaction. One novelty in this research is that in the Indonesian context, a similar research has never been carried out in just one company because in other studies it was conducted in general, the choice of Traveloka made the research more focused on the largest online travel agency company in Indonesia.

\section{LITERATURE REVIEW}

In the next six months, about half of Indonesian consumers expect to purchase online air tickets (55 percent) and book hotels and travel agents (46 percent). Four out of ten customers (40\%) are planning to buy electronic books (ebooks), almost four out of ten customers are planning to buy apparel / footwear / shoes (37\%), and more than one-third of customers are planning to buy online event tickets (34\%) (Suwarni et al., 2020). In other words, the findings of the survey indicate that customers are more likely to buy travel services online. Thus the advent of e-commerce has also helped promote Indonesia's tourism industry since it has caused the emergence of airline ticket sales and hotel booking sites.

The experiences of tourists visiting tourist objects visited are heavily affected by the tourism industry. If a positive experience is the perception of tourists who come, then this news will spread to other tourists and attract visitors to these tourist destinations. Yet, on the other hand, If the impression of tourists visiting a tourist attraction is negative, it will decrease or even drop the tourist visit to these attractions. At present, Indonesian tourism is greatly supported by technological advances, one of which is internal tourism.

With the aid of the internet, travelers can easily access different data about a tourist attraction. Other tourists can easily access all the views of tourists who have visited a tourist attraction, one of which is through Online Travel Agencies (OTAs) that are currently prevalent in Indonesia. 
Traveloka is one of the fastest growing technology companies in Southeast Asia. Traveloka is a site for searching and booking flight tickets and hotels in Indonesia. Traveloka was founded in 2012 and headquartered in Jakarta, Indonesia. Traveloka has formed partnerships with various domestic and international airlines, namely more than 18,000 different routes throughout Asia Pacific. Traveloka has registered into its network thousands of hotels throughout Southeast Asia, Hong Kong, South Korea and Australia.

Traveloka is one of the fastest growing technology companies in Southeast Asia. Traveloka is a site for searching and booking flight tickets and hotels in Indonesia. Traveloka was founded in 2012 and headquartered in Jakarta, Indonesia.

In addition to ease of use and pleasant taste, attempts to attract customers to shop online are also linked to certain exogenous factors such as market characteristics, situational factors, product characteristics, previous online shopping experience and confidence (Weisberg et al., 2011). The reliability of the information given by the website has an impact on the intentional conduct of the user. An accurate website offers information that is considered valuable and trustworthy to tourists and is efficiently received when the information is delivered in an attractive manner (Semeijn et al., 2005).

The development and use of technology today is growing rapidly, starting with increasingly sophisticated computers and smartphones in use that continue to experience changes and improvements in technology (Sutia et al., 2019). At the beginning of the presence of computers and the internet were only used in terms of marketing company products and services, however at this time there have been many changes, especially in terms of trade such as E-trade and payments made in non-cash with several sophisticated devices such as E-banking and mobile banking (Putri and Baridwan, 2014).
E-commerce plays an important role for companies to stay competitive in the global market. Companies are progressively adopting e-commerce systems, where they are seen as a stage procedure, where the company initially outweighs the reasons for ecommerce adoption. There are several advantages of e-commerce over traditional commerce, which are relatively applicable to all companies. For example, e-commerce leads to supply chain disintermediation, which means that companies can eliminate expensive sales agents and reduce costs. In addition, e-commerce provides access to distant markets because it is said to blur international boundaries (Suwarni et al., 2020).

It seems a sensible decision for many companies to explore e-commerce opportunities due to globalization in the business sector and the increasing importance of doing business internationally. The availability of e-commerce software and supporting institutions is a big factor for e-commerce adoption. Once the company chooses to engage in e-commerce, the implementation process begins. During this process, it is important for companies to distinguish between the enablers and barriers to ecommerce implementation. E-commerce is a tool through which companies can achieve a competitive advantage. Therefore, it is interesting to further explore how companies actually implement e-commerce systems and the paths they take from generating e-commerce ideas to realizing ecommerce success. Also, large companies are bound to adopt new technology rather than small companies because of economies of scale. Another interesting context to study is the industrial context, because implementing e-commerce requires different competencies in various sectors of the economy (Fahlevi et al., 2019).

The term Unicorn, has a different meaning in terms of funding in the business world. Unicorn is associated with any tech startup business company that can reach a market value of $\$ 1$ billion as summed up by 
private or public spending. This term was originally mentioned by Aileen Lee, founder of Cowboy Ventures. Unicorn is considered as a phenomenon that occurs in Human Resources, when the person supervising the recruitment of candidates has impossible expectations for those they recruit. This forms the difference between the expectations of the employer and the labor available in the market. Basically, Human Resources is looking for mythical candidates (unicorns) than those available in the market (Suwarni et al., 2020).

Basically, Startup is the implementation of a business plan where everything that has been planned and projected in the business plan is poured out and realized in the form of a startup. There was no mention of the size of the company or industry sector. Startup valuation is the economic value of a business that involves startup companies. Assessment is usually used as a reference to measure how much business potential a company has. Quoting Tech in Asia, startup calculations and conventional company valuations are not much different. Conventional company valuation considers several aspects including the company's value on exchange shares, the value of other types of shares owned by the company, the company's debt, and the companies that have cash (Istan and Fahlevi, 2020).

Meanwhile, startups that have not yet earned an income or profit since the early stages of their business position. Company founders or potential investors will consider aspects such as number of transactions and nominal, number of users, product technology, team quality, and competitors. Companies that pocket unicorn status based on assessments developed by venture capitalists and investors who participate in funding rounds. All unicorns are actually startups, only their value is judged based on the potential for growth and business development.

The current research used as a guide clarified the effect of online marketing and brand recognition and finally influenced the online travel agent's satisfaction and customer behavior in China (Gao and Bai, 2014). This paper aims to extend previous research by exploring not only the influence of digital marketing on increasing consumer behavior, but also seeks to explore the link between digital marketing and brand recognition to create a positive impact on customer satisfaction (Kim et al., 2007).

The definition of behavioral intention refers to the probability that customers will return to the business they have used, which can be seen as an indication indicating where a customer wishes to remain a customer or quit the business they have served (de Luna et al., 2019). For businesses that can not be overlooked because it helps clients to return in the future, this situation has grown as a profitable investment (Singh et al., 2017).

The purpose of behavior can define the degree to which a person formulates a deliberate strategy in the future to do or not do any behavior (Foroughi et al., 2016). There are two classes of behavioral intention, namely positive and negative (Durna et al., 2015), the intention to prescribe, the intention to reuse and the approval of higher prices are usually positive conditions (Durna et al., 2015), negative, vice versa, consists of complaints to friends or external institutions, turning to rivals and reducing the company's amount of business (Foroughi et al., 2016).

Sales development can raise the size of the business of the travel agent to a larger level, as sales are closely linked to the company's profitability, the more businesses will make significant profits, so many investors will be interested in investing their funds in the company. In corporate terms, This phenomenon is very beneficial for the business to survive and compete in the online travel agent industry especially for the long term.

Advertising is commercial and non-personal communication about an organization and its products that are transmitted to a target audience through mass media such as 
television, radio, newspapers, magazines, direct mail (direct posting), outdoor billboards, or public transportation (Kotler and Keller, 2016).

Some e-commerce usually use the following types of ads for their promotion (Madan and Yadav, 2016). Pull Demand Advertising is advertising aimed at end buyers so that demand for the relevant product increases. Usually, producers advise consumers to buy their products from the nearest seller. Pull demand advertising is also called consumer advertising (Madan and Yadav, 2016).

Push Demand Advertising is advertising aimed at distributors. This means that distributors are willing to increase demand for the product concerned by selling as much as possible to buyers/retailers. Goods advertised are usually industrial goods. Push demand advertising is also called trade advertising Pull Demand Advertising is advertising aimed at end buyers so that demand for the relevant product increases. Usually, producers advise consumers to buy their products from the nearest seller. Pull demand advertising is also called consumer advertising (Madan and Yadav, 2016).

Push Demand Advertising is advertising aimed at distributors. This means that distributors are willing to increase demand for the product concerned by selling as much as possible to buyers/retailers. Goods advertised are usually industrial goods. Push demand advertising is also called trade advertising Pull Demand Advertising is advertising aimed at end buyers so that demand for the relevant product increases. Usually, producers advise consumers to buy their products from the nearest seller. Pull demand advertising is also called consumer advertising. Push Demand Advertising is advertising aimed at distributors. This means that distributors are willing to increase demand for the product concerned by selling as much as possible to buyers / retailers. Goods advertised are usually industrial goods. Push demand advertising is also called trade advertising
Therefore by introducing promotion techniques, online travel agencies have to survive in order to increase their repurchase purpose and also to meet their consumer needs. This study therefore emphasizes the investigation of the link between online marketing promotion, consumer satisfaction and customer intention to repurchase services.

\section{Hypothesis Development}

In order to gain comfort in performing transactions, customers who prefer to shop online retail (Slade et al., 2015). In the sense of Business to Consumer (B2C), online marketing must be well planned, according to Ranganathan and Ganapathy (2002), so that customers can get the desired product details quickly. Several empirical studies show that quick access to online shopping sites will improve customer loyalty (Chung and Shin, 2008).

$\mathrm{H}_{1}$ : Marketing promotion affects the satisfaction of online travel agent customers in Jakarta.

Customer satisfaction has always been the subject of attention of researchers and marketing professionals in recent decades. The emphasis stems from a theory that states that achieving business success relies on the ability of the organization to deliver what customers want. In other words, customer satisfaction is the secret to business success (Das Guru and Paulssen, 2020). In addition, Ngo and Nguyen (2016) clarify that consumer loyalty generates consumer retention that can further improve company income, provided that the cost of keeping current customers is lower than the cost of finding new customers.

More precisely, Horppu et al. (2008) notes that website satisfaction has a positive influence on website confidence in the sense of online business. Continuous satisfaction increases trust, which is the product of satisfaction associated with individual purchases over time (Madan and Yadav, 2016). The combination of satisfaction and confidence is a condition that promotes the 
creation of long-term customer relationships characterized by loyalty-based engagement (Kim et al., 2011).

$\mathrm{H}_{2}$ : Customer Satisfaction Affect Repurchase Decision Online Travel Agent in Jakarta.

In order to gain competitive advantage, online marketing and customer loyalty are a company's performance factors (Gwebu et al., 2014). Judging from the highest level of service will generate satisfaction for clients. Consumer satisfaction is a measure of customer preferences and business goods or services as long as consumers use the products or services of the company (Madan and Yadav, 2016).

The company's attention is growing from pnline marketing to customer satisfaction, with many of the businesses setting their emphasis through customer satisfaction. When shopping or using company services, to find customer loyalty is to see their level of satisfaction. Customer satisfaction information definitely adds feedback and can be used as a basis for business enhancement to boost service quality initiatives as a way to increase customer loyalty (Yoon and Tran, 2011). In a study conducted by Yoon and Tran (2011), online marketing had a positive impact on consumer loyalty in the form of customer satisfaction repurchases..

$\mathrm{H}_{3}$ : Online Marketing Affect Repurchase Decision Online Travel Agents Through Customer Satisfaction In Jakarta.

\section{RESEARCH METHODS}

Online marketing as $\mathrm{X} 1$ variable independent (X1 variable independent). Online marketing is online marketing via an online interactive computer system that electronically links consumers with sellers.

As an intermediate variable Y1 (dependent variable Y1), customer satisfaction. After comparing what he gets and his desires, client satisfaction is the level of customer feelings (Andhini, 2017). A consumer is very likely to remain a customer for a long time, if pleased with the value offered by a product or service.

Decision to repurchase consumers as a Y2 dependent variable (Y2 dependent variable). Repurchase decisions are actions from which customers buy the same product.

Every element of research is population (Saunders et al., 2009). The Traveloka users in Jakarta are part of population study. The sample is part of the population under study or is representative of it (Stapleford, 2017). In the Jakarta area, Traveloka users were the research sample. Since the population of the Jakarta area does not precisely count the number of Traveloka users, the author uses Joseph F. Hair's theory.

The calculation of the sample size of a population that can not be measured is as follows, according to Hair et al. (2011):

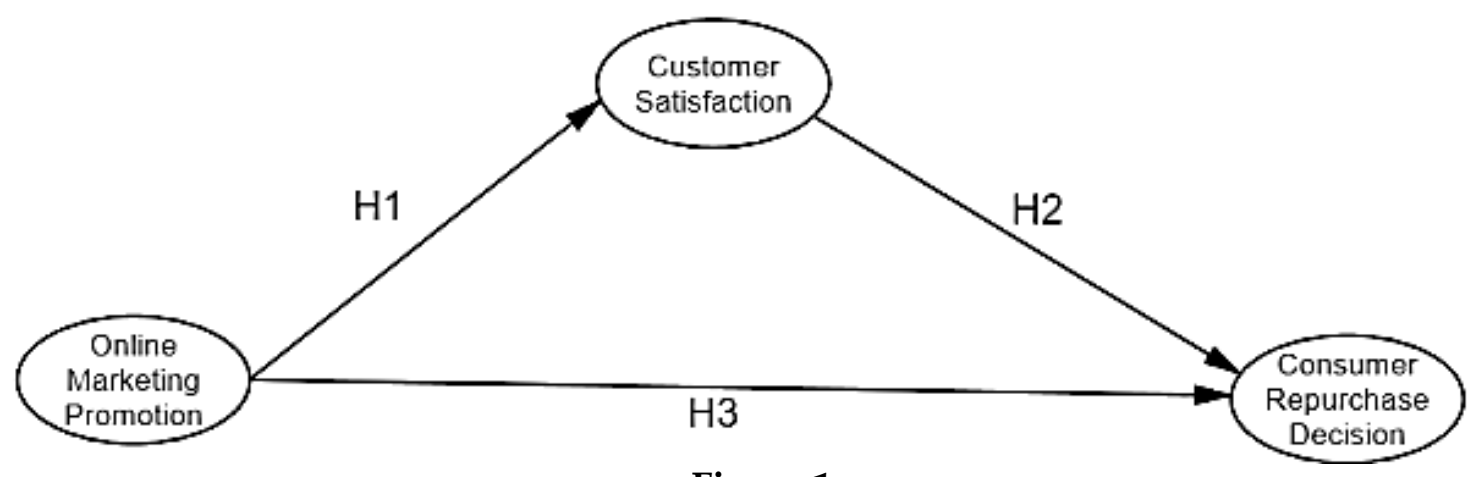

Figure 1

Source: Researcher (2020)

Research Model 
- Over 30 samples are recommended.

- A sample of about 100 is deemed appropriate for market surveys.

- Or the independent variable varies from 15 to 20 times.

From the above theory, it will fit into the business survey point if connected to analysis, where a sample of about 100 is considered sufficient, so the authors set a total sample of 100 individuals.

SmartPLS is commonly used in complex models and uses many variables, the reason for choosing SmartPLS is because this software belongs to the non-parametric variance based group so that data analysis does not require the obligation to be normally distributed and can be used with minimal data, namely under 100 samples, even though this study uses 100 samples for the data analysis process. SmartPLS in the analysis uses the bootstrapping method or random multiplication, so that the assumption of normality is not mandatory for the use of SmartPLS. Ultimately, SmartPLS does not require a minimum sample size due to the bootstrapping process. Research that has a small sample can still use SmartPLS is often used as predictive analysis and theoretical confirmation in several studies.

The causal relationship developed in this study uses a model that is not clear, so it needs analytical tools that can explain the relationship, and the Partial Least Square 3 software is the inferential statistical approach used in research data analysis.

The authors used reflective model in this analysis. A construct where what can be seen is represented as a function of the construct (the object represents or is a representtation of the construct) is indicated by reflexive indicators (Hair et al., 2017).

SmartPLS used in this study aims to predict the relationship between constructs, because SmartPLS is different from other SEMs such as CBSEM, which is a parametric group, which can confirm theory, but SmartPLS can only predict so that this is not a shortage of SmartPLS in processing variant-based data. however, SmartPLS serves as a complement to research using SEM for research that cannot use CBSEM because it has to fulfill the assumption of data normality which is quite difficult to do in human resource research with a minimal number of samples. The reasons for using PLS-SEM in this study are as follows:

- The purpose of this study is to predict repurchase decision constructs or identify the main predictor constructs.

- This research is an exploration or extension of the existing structural theory.

- The structural model is quite complex (many constructs and many indicators).

- The sample size is low.

In testing the hypothesis, an analysis is carried out on the SmartPLS output results by looking at the P-value and T-statistics of these two elements as the basis for making decisions on each hypothesis whether the hypothesis is accepted or rejected. In this study, several hypotheses will be tested using PLS, if the P-value is less than 0.05 then the hypothesis is accepted and $\mathrm{H}_{0}$ is rejected or can use T-statistics as a reference for decision making whether the hypothesis is accepted or rejected if the Tstatistics is more than T-Table. Hypothesis is accepted and $\mathrm{H}_{0}$ is rejected. In the end, all data is processed and the results of the SmartPLS output will be interpreted to determine whether the hypothesis is accepted or rejected based on these provisions (Hair et al., 2011).

\section{ANALYSIS AND DISCUSSION}

In this study, data analysis used confirmatory first order. For the purposes of data analysis using Smart PLS 3, the authors draw a route diagram based on the study variables and research indicators. Building a path diagram of a causal relation that has been established is a must in the Structural Equation Model. The path diagram makes it simple for researchers to evaluate causal 
relationships and analyze the path to estimate the strength of causal relationships.

This model uses reflective indicators, therefore reliable measurements are needed for each construct, namely Partial Least Square (PLS). By calculating the convergent value or reliable loading as reliable confirmation that can measure the construct. Limit the size of the indicator value if it correlates more than 0.7 with the construct to be measured. However, for initial research and development a measurement scale of 0.5 to 0.6 is considered sufficient (Hair et al., 2010). In this study we used a general theory that was used using 0.5 so that the items were very valid in measuring variables so that the study could be more accurate. Another measure is the Average Variance Extracted (AVE) value. AVE value describes the amount of variance or variety of manifest variables that can be had by latent constructs. In statistics (classical test theory), the mean of variance extracted (AVE) is a measure of the amount of vari- ance captured by the construct in relation to the amount of variance due to measurement error. A minimum AVE value of 0.5 indicates a good measure of convergent validity.

All research variables have a high convergent validity value based on the factor loading values above (figure 2), if the indicators have a loading factor above 0.5 and are important, then all indicators are said to be true in the research variable. For each predictor, the following table describes the loading factors and statistical $\mathrm{T}$ values .

All research variables have a valid convergent validity value based on the factor loading values, if the indicators have a loading factor above 0.5 and are important, then all indicators are said to be true in the research variable. The research model will turn to the image below (figure 3) after the invalid indicators are removed.

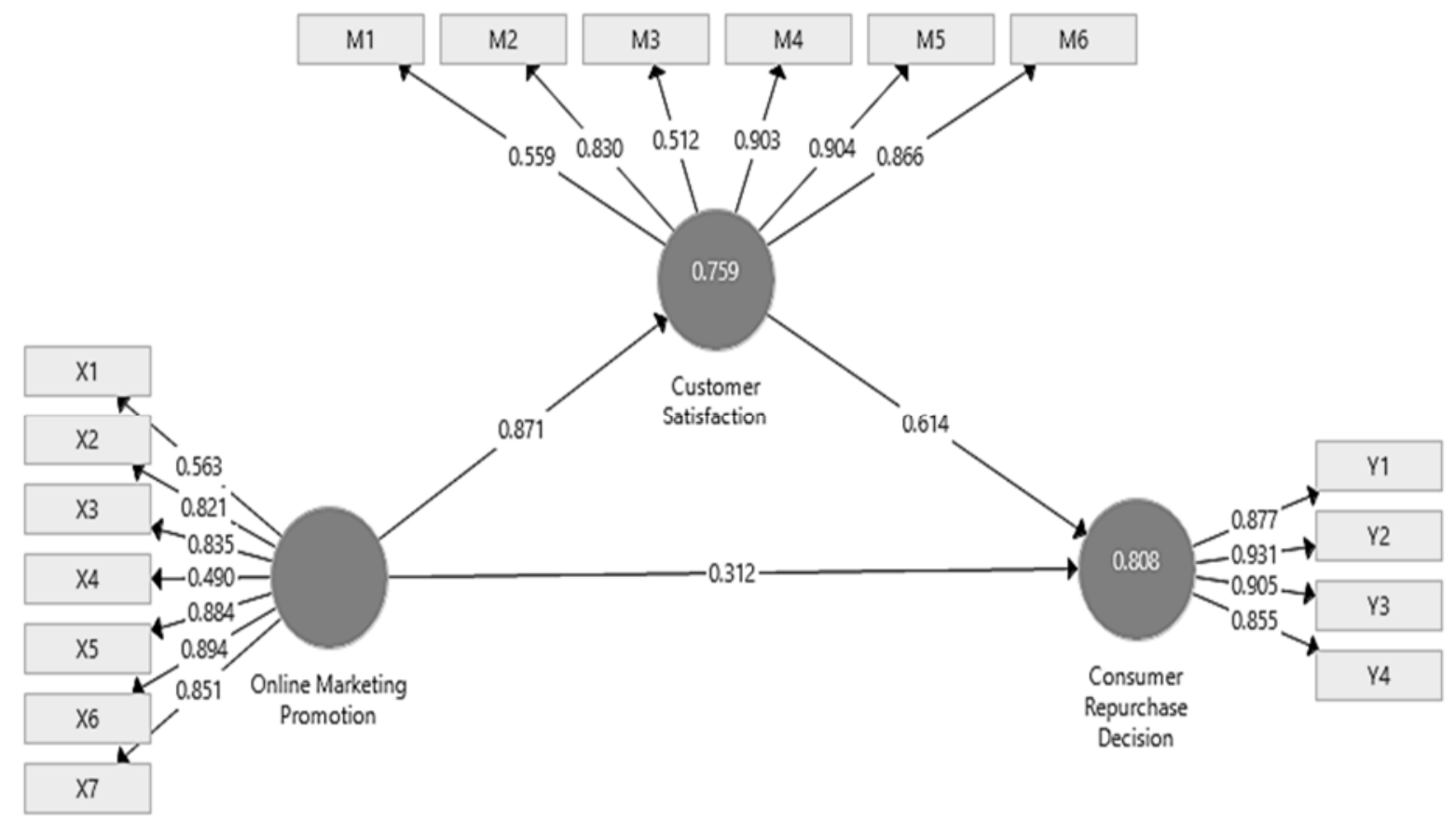

Figure 2

Source: SmartPLS 3

\section{Outer Model}




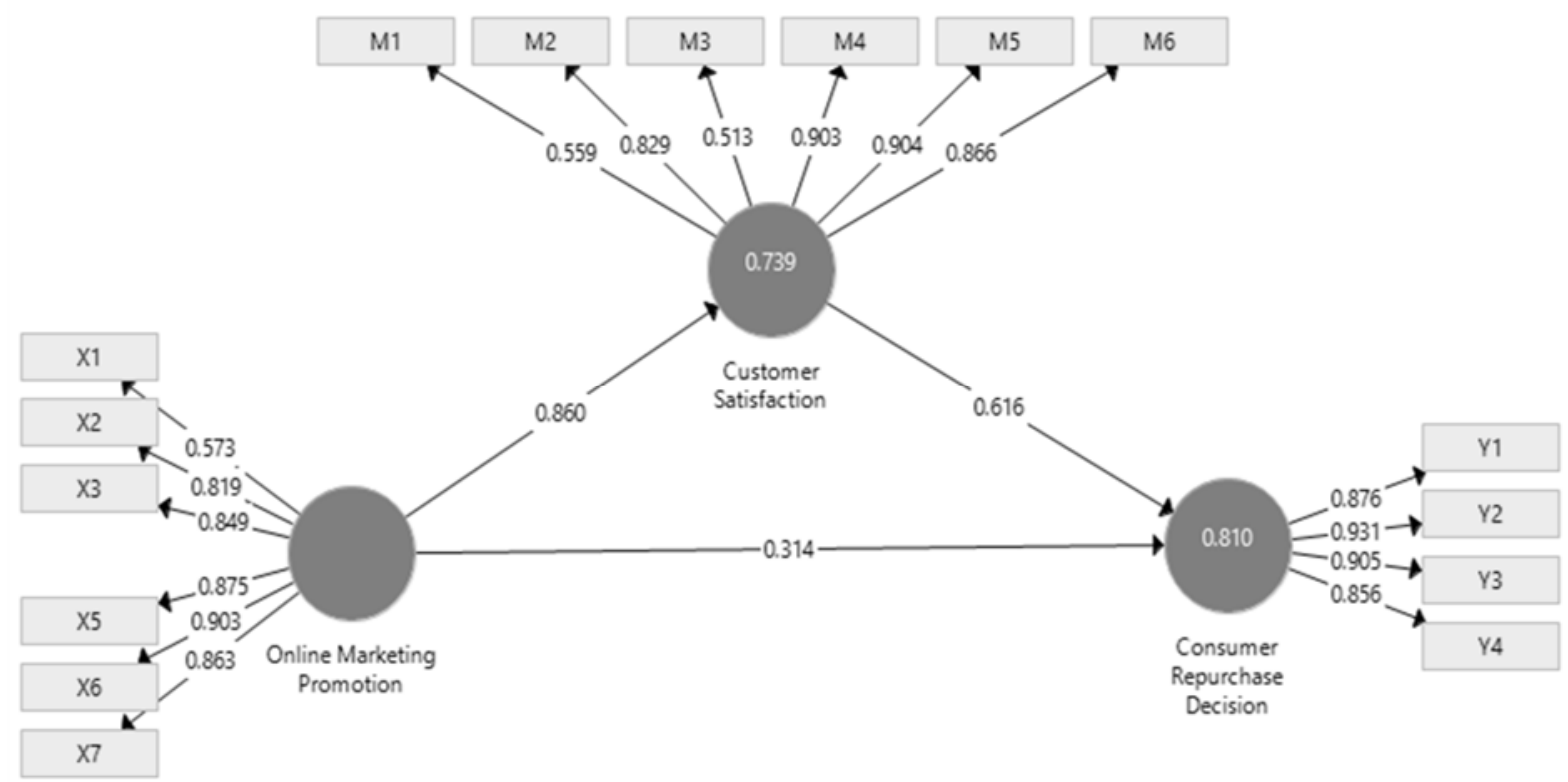

Figure 3

Source: SmartPLS 3

New Research Model

In the next section, the reliability of the indicators is measured to find out if the question is repeatedly given to the same person, the answer given is the same. Measuring whether an indicator is reliable needs to be seen from Cronbach's alpha results of more than 0.7, although there are some experts who say that it is allowed as long as it is above 0.5 in the note that the model has low reliability (Saunders et al., 2009).

A variable is said to be very accurate in research if the variable has a value of build reliability greater than 0.7 . Table 1 is the results of reliability testing on each of the research variables is given below.

Table 1

Reliability

\begin{tabular}{ll}
\hline \hline \multicolumn{1}{c}{ Variable } & Cronbachs Alpha \\
\hline OM & 0.811 \\
CS & 0.834 \\
RD & 0.946 \\
\hline
\end{tabular}

Source: SmartPLS 3

It can be assumed that all study variables have alpha cronbachs above 0.7 on the basis of the results of the reliability performance above.

Predictive-relevance $(\mathrm{Q} 2)$ values are used to determine the structural model consistency of fit. The magnitude of predicttive relevance $(\mathrm{Q} 2)$ is determined using the formula below:

$$
\mathrm{Q} 2=1-(1-\mathrm{R} 21)(1-\mathrm{R} 22) \ldots \mathrm{n}
$$

$\mathrm{R} 2$ is the decision coefficient that is part of the overall variation in the dependent variable that is explained by the independent variable's variations. The results of the study of the coefficient of determination for the research variables are explained in Table 2 below.

Table 2

R-Square

\begin{tabular}{ll}
\hline \hline \multicolumn{1}{c}{ Variable } & R-Square Value \\
\hline CS & 0,721 \\
RD & 0,846 \\
Predictive-Relevance $\left(\mathrm{Q}^{2}\right)$ & 0,957 \\
\hline
\end{tabular}
Source: SmartPLS 3 


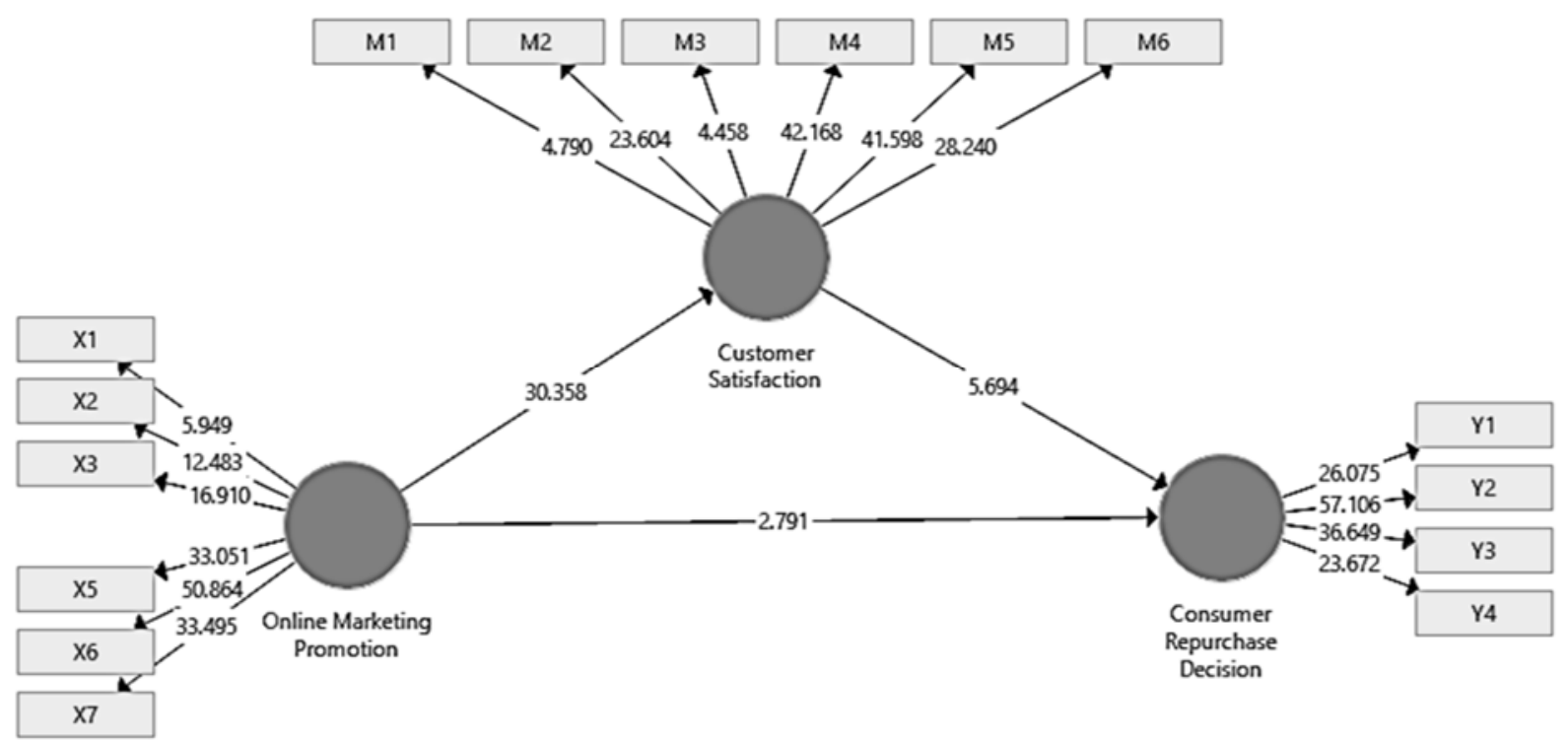

Figure 4

Source: SmartPLS 3

Inner Model

The $\mathrm{R}$ Square value for customer satisfaction variable is 0.721 based on the determination coefficient in the table above which means that the value implies that differences in customer satisfaction can be explained by online marketing promotion of 72.1 percent.

The $\mathrm{R}$ Square value is 0.846 for the consumer repurchase decision variable, which means that the consumer repurchase decision is clarified by 81 percent of the online marketing promotion variable and customer satisfaction.

Although the predictive relevance value in this study for the structural model is 0.957 or 95.7 percent, the model can explain 95.7 percent of the repurchase decision phenomenon.

To test the hypotheses in this study, partial tstatistic values are used for each direct influence pathway. The following is a picture (figure 4) that explains the path diagram for hypothesis testing.

At this stage is to measure the amount of influence to test the hypothesis, the value of the coefficient of influence between constructs is used to determine the effect directly or indirectly. According to Hair et al. (2011) The procedure of creating a predetermined large number of bootstrap samples (eg 5,000) by drawing cases randomly with replacement from the original sample. Each bootstrap sample must have the same number of cases as the original sample. The PLS algorithm estimates the SEM results from each bootstrap sample (for example, 5,000 PLS-SEM estimates). The repeated bootstrap parameter estimates are then used to construct the empirical sampling distribution for each model parameter, and the standard deviation of the empirical sampling distribution is used as a proxy for the empirical standard error rate for that parameter. One way to understand this choice is to consider the existing sample to be the best representation of budget hotel employees from the underlying population. This thesis may not have the entire population to sample from others, but the data of this thesis have special population represent-tation. Completely random resampling of this population representation means that it is used as a sample by replacement, resam-pling by resampling is done because it is the right thing to do, given that the model behind the bootstrap is to use a non-para-metric maximum likelihood to estimate the 
cumulative distribution function, then take a sample of independent observations from the estimated cumulative distribution function.

The obtained path model coefficients form a bootstrap distribution, which can be viewed as an estimate of the sampling distribution. The PLS-SEM results of all bootstrap samples provide standard errors for each path model coefficient. With this information, the t-test in the study can be conducted to measure the significance of the path model relationship.

Both indicators on each variable have a statistical value greater than 1.96 on the basis of the above hypothesis testing route diagram, so that these indicators are capable of measuring each build. Meanwhile the statistical value of the Smart PLS production is compared with the value of the table to assess the relationship between variables (hypothesis testing). Table 3 below provides the outcomes of relationships between constructs (variables).

Table 3

Path Analysis

\begin{tabular}{lll}
\hline Hypothesis & P Values & \multicolumn{1}{c}{ Information } \\
\hline H1 & 0,000 & Significant \\
H2 & 0,000 & Significant \\
H3 & 0,000 & Significant $^{* *}$ \\
\hline
\end{tabular}

Source: SmartPLS 3

The findings of the study provide us with knowledge that online marketing promotion and customer satisfaction have a major impact. This is the same as previous research conducted and in the Business to Consumer (B2C) sense, online marketing must be well planned so that customers can get the desired product details quickly. Several empirical results suggest that online shooping is easy to access sites can increase customer satisfaction (Syapsan, 2019).

This research also provides us with knowledge that customer loyalty and consumer repurchase decisions have a major impact. This is the same as previous studies conducted by Ramadan and Aita (2018) show that consumer loyalty generates retention of customers that can further boost company income, provided that the cost of keeping current customers is cheaper than the cost of seeking new customers. More precisely, Horppu et al. (2008) notes that website satisfaction has a positive influence on website confidence in the sense of online business. Continuous satisfaction increases trust, which is the product of satisfaction associated with individual purchases over time (Elbeltagi and Agag, 2016).

In the third hypothesis, the researchers found that online marketing promotion significantly influenced consumer repurchase decisions through customer satisfaction, and this was in line with and close to previous research conducted by (Hussain et al., 2020), from web marketing to customer loyalty, the company's emphasis is growing, By client satisfaction, many of the businesses set their orientation. When shopping or using company services, to find customer loyalty is to see their level of satisfaction. Customer satisfaction knowledge undoubtedly adds feedback and can be used as a foundation for business enhancement to be better in terms of service quality initiatives as a step towards increasing customer loyalty (Chung and Shin, 2008). In a research carried out by Semeijn et al., (2005) internet marketing has been found to have a substantial positive impact on consumer loyalty in the form of repurchases through customer satisfaction.

An intense promotion must be followed by attractive services so that the public does not turn away. One of the keys to success that enabled Traveloka to provide hotel rooms and cheap flight tickets is the Best Price Guarantee program, which guarantees the cheapest ticket prices. If customers find cheaper ticket prices on other sites, Traveloka will provide ticket vouchers with a certain value. In short, the concept of success adopted by Traveloka is to focus on offering the best and innovative products and services to all consumers through large strategic promotions. 
Currently, Traveloka has collaborated with 27 international and domestic airlines serving tens of thousands of routes in the Asia Pacific region. As for hotel room service, Traveloka has collaborated with thousands of hotels spread across Indonesia to Hong Kong.

For modern society, the use of airplanes is no longer a luxury but has become a primary need. When it comes to traveling long distances in a short time, the plane is one of the transportations that will be the main choice for every community. With a short trip it will make airplane passengers save time and effort, therefore the community needs a good media that can provide sufficient information to make choices about the various types of airlines that are offered to be used as a tool to support decision making to buy flight tickets.

Traveloka appeared at the right time. When Indonesian people are passionate about going on tours. With its initial service providing a variety of flight tickets, it is certain that Traveloka is flooded with visitors on its website looking for the cheapest series of flight tickets. This is coupled with the complementary features at Traveloka which provide a variety of hotel choices for its consumers to spend the night. Traveloka's strategy has been advocated by many consumers because of the satisfaction of our customers, which makes customers willing to promote our products to people.

The success of Traveloka being advocated by its customers cannot be separated from Traveloka's mission to provide an interesting experience for all its customers. At least in 2016, there were several additional features that made consumers more comfortable and comfortable using Traveloka services, one of which was the Price Alert feature.

Airline ticket prices are very volatile, while consumers always consider affordable prices. Traveloka's strategy is to bring up this feature to make it easier for customers to decide what flights to use, of course according to the budget that has been budgeted.

In addition, Traveloka also raises the Reschedule feature. Previously, the process of rescheduling airline tickets seemed a hassle because consumers had to contact the airline by telephone. This sometimes becomes an obstacle for our customers because the ordering and changing process must go through two doors. This new feature allows users to easily change their orders on Traveloka online, via the website or mobile application. Currently, Traveloka has provided more than 70 airlines, both domestic and international. This is coupled with the 100,000 routes available on Traveloka.

Traveloka has also succeeded in introducing a campaign that is easy for the public to remember in 2016, namely Traveloka first, Traveling later. This campaign is part of the number of consumers who share their experiences using Traveloka services. So when you want to travel, always remember the Traveloka service.

The development of the modern era, especially in the field of communication, has had a significant impact in various fields, especially in the economic sector. Business people in carrying out their marketing activities are now trying to determine a marketing strategy to reach their target market. The number of global competition and the many market challenges require companies to continue to innovate and be creative in formulating promotional strategies and programs in order to compete.

One of the things that can be done to deal with this is by using marketing communications through promotions that can be conveyed properly to consumers. An example of the real impact of this communication era is the growth of the internet in a world that is often touted as new media. From a series of new technologies created with all its sophistication and complex systems, the internet emerged in the mid1900s as a new mass media that was very 
powerful. Of course, with the presence of the internet at this time, it has supported the effectiveness and efficiency of the company's operations, especially its role as a means of communication, publication, as well as a means of obtaining various information needed by a company in responding to the lifestyle of today's society.

Tourism is one of the sectors hit by the corona pandemic. Online travel service provider (OTA) startup business, Traveloka was also affected hotel occupancy rates fell to their lowest level. Domestic and regional lifestyle activity partners, as well as restaurants, have even had to temporarily close business operations due to the Covid-19 pandemic. Even so, he is optimistic that his company will bounce back with the rapid adjustment of business strategy. In Indonesia and Vietnam, for example, companies see the domestic travel sector as well as short-distance entertainment activities starting to grow, even though there is still a pandemic. Traveloka business in Vietnam is starting to stabilize and is approaching the pre-pandemic period. Meanwhile in Thailand, it is almost over $50 \%$ compared to the normal situation.

Therefore, Traveloka is working with industry partners and other stakeholders. In addition, implementing various steps for business optimization in order to make savings and refocusing on preparing strategies to welcome the new normal era (new normal). Traveloka also continues to present innovative products for users, which is the main focus. One of them is combining Covid-19 risk testing services and airplane tickets. Then, order hotel vouchers with flexible stay periods through Buy Now Stay Later, the Online Xperience program, live streams from Traveloka LIVEstyle Flash Sale, and the Traveloka Clean campaign.

Then, presenting a donation package starting from Rp. 11 thousand to Rp. 27 thousand per portion to support Traveloka Eats restaurant partners last May. Then, the company provided risk testing services for contracting Covid-19 in 44 cities in June.
Traveloka also promotes flash sales through the live streaming feature on social media. The company is aggressively marketing products with content about staycations, road trips, and others in accordance with health protocols.

One of the partners, The Alana Hotel and Conference Center Malioboro Yogyakarta, stated that room bookings at that time increased by $1,100 \%$ compared to before the discount. Traveloka also notes that transactions have begun to increase, although they have not returned to their pre-pandemic conditions. Realizing this potential, the company launched the Buy Now Stay Later feature for accommodation and Time Machines from Traveloka Xperience. This allows users to book services in advance, while staying or traveling is determined later. In the same month, the company also launched a live broadcast feature on the Traveloka LIVEstyle platform. A month later, this startup provided a rapid test service for the risk of contracting the corona virus at Soekarno Hatta Airport. To be able to fly by plane, prospective passengers must have a Covid-19 free certificate based on the results of the rapid test and PCR.

Then, hook up eight airlines that allow users to change flight schedules many times at no additional cost. Companies invited to work together are Garuda Indonesia, All Nippon Airways, Cathay Pacific, Singapore Airlines, Scoot, Jetstar, Japan Airlines, and American Airlines. Most recently, Traveloka launched a virtual tour, this is an opportunity and paved the way in the seven countries where Traveloka operates.

Problems faced by travelers are generally not far from accommodation prices and availability of departure schedules. Therefore, the Best Price Guarantee feature is here to provide a price guarantee. As an illustration, if we find cheaper airfare and hotel prices elsewhere, just make a claim and the "loss" is paid. Then, Refund \& Easy Reschedule are provided as help when the holidays don't go according to plan. With it, we can apply for a refund with a fast pro- 
cess, and last but not least be pocket-friendly, or change the departure schedule easily.

Traveloka, which was originally limited to a search engine for comparing flight ticket prices from various sites, now also offers train, bus, and even travel tickets as a convenient and affordable alternative to traveling. Not only that, airport shuttle service options to car rental are also available lately.

This research implies that in applications, especially tourism service provider applications, and perceived company value can indirectly influence users to use these applications. There are other factors that can affect user perceptions of an application, attractive prices and promos, translation security, suggestions from users who already use and even impressions of users using the application. By paying attention to these factors, the application development company can also encourage users to continue to use the application to meet their needs.

From the results of the description of the phenomena and symptoms above, where the Traveloka website is a company that is classified as starting to rely on this community trying to provide its services to inform aircraft promotional ticket prices to consumers, so that researchers are interested in seeing the effect of the effectiveness of the Traveloka website on the satisfaction of the information needs for promotional ticket prices to consumers (Sutia et al., 2019).

The growth in the number of consumers who shop online continues to increase, so the use of information and communication technology needs to be developed to further encourage online development. Must be able to survive in business competition through internet media and able to improve the quality of service better so that consumers are satisfied and loyal to the selected product. It is hoped that the next researcher can develop this research by adding other variables that can affect customer satisfaction and can use other research methods such as qualitative inter- view data collection in order to obtain more complex results.

\section{CONCLUSIONS AND SUGGESTIONS}

The findings of this study provide evidence that the promotion of online marketing is essential for the marketing and business growth of an online company such as Traveloka. In addition, it is important to consider customer satisfaction as an intervening variable that both directly and as a mediating variable between online marketing promotion and repurchase decision making has a major effect on consumer repurchases. The $\mathrm{R}$ square value that is so high between the relationships between variables both directly and indirectly provides information that both variables affect the variable of repurchase decision is sufficiently large so that online travel entrepreneurs, especially Traveloka, which is the focus of this study, need to consider this issue.

The findings of the study provide us with knowledge that online marketing promotion and customer satisfaction have a major impact. This is the same as previous research conducted and in the Business to Consumer (B2C) sense, online marketing must be well planned so that customers can get the desired product details quickly. Several empirical results suggest that online shooping is easy to access sites can increase customer satisfaction (Syapsan, 2019).

This research also provides us with knowledge that customer loyalty and consumer repurchase decisions have a major impact. This is the same as previous studies conducted by Ramadan and Aita (2018) show that consumer loyalty generates retention of customers that can further boost company income, provided that the cost of keeping current customers is cheaper than the cost of seeking new customers. More precisely, Horppu et al. (2008) notes that website satisfaction has a positive influence on website confidence in the sense of online business. Continuous satisfaction increases trust, which is the product of satisfaction 
associated with individual purchases over time (Elbeltagi and Agag, 2016).

In the third hypothesis, the researchers found that online marketing promotion significantly influenced consumer repurchase decisions through customer satisfaction, and this was in line with and close to previous research conducted by Hussain et al., (2020), from web marketing to customer loyalty, the company's emphasis is growing, By client satisfaction, many of the businessses set their orientation. When shopping or using company services, to find customer loyalty is to see their level of satisfaction. Customer satisfaction knowledge undoubtedly adds feedback and can be used as a foundation for business enhancement to be better in terms of service quality initiatives as a step towards increasing customer loyalty (Chung and Shin, 2008). In a research carried out by Semeijn et al., (2005) internet marketing has been found to have a substantial positive impact on consumer loyalty in the form of repurchases through customer satisfaction.

\section{REFERENCE}

Adila, T. M., W. S. Bintang, R. B. Ikhsan, and M. Fahlevi. 2020. Instagram as Information in Developing Purchase Intentions: The Role of Social E-wom and Brand Attitude. Proceedings of 2020 International Conference on Information Management and Technology, ICIMTech 2020.

Adiyanto, H. and A. G. Subakti. 2018. Pengaruh Pelatihan, Motivasi dan Kompetensi Terhadap Kinerja Karyawan (Studi Kasus Hotel Sahid Jaya Lippo Cikarang). Journal of Indonesian Tourism, Hospitality and Recreation 1(2): 55-69.

Andhini, A. 2017. Pengaruh Transaksi Online Shopping, dan Kepercayaan Konsumen terhadap Kepuasan Konsumen pada E-Commerce. Jurnal Ilmu Dan Riset Manajemen 6(7): 1-23.

Badan Pusat Statistik. 2018. Statistik Hotel Dan Akomodasi Lainnya Di Indonesia. BPS Statistics Indonesia, 186.
Chung, K.-H. and J.-I. Shin. 2008. The Relationship among E-retailing Attributes, E-Satisfaction and E-Loyalty. Management Review: an International Journal 3(1): 23-45.

Das Guru, R. R. and M. Paulssen. 2020. Customers' Experienced Product Quality: Scale Development and Validation. European Journal of Marketing 54(4): 645670.

de Luna, I. R., F. Liébana-Cabanillas, J. Sánchez-Fernández, and F. MuñozLeiva. 2019. Mobile Payment is not All the Same: The Adoption of Mobile Payment Systems Depending on the Technology Applied. Technological Forecasting and Social Change 146: 931-944.

Durna, U., B. B. Dedeoglu, and S. Balikçioglu. 2015. The Role of Servicescape and Image Perceptions of Customers on Behavioral Intentions in the Hotel Industry. International Journal of Contemporary Hospitality Management 27(7): 1728-1748.

Elbeltagi, I., and G. Agag. 2016. E-Retailing Ethics and Its Impact on Customer Satisfaction and Repurchase Intention: A Cultural and Commitment-Trust Theory Perspective. Internet Research 26(1): 288-310.

Fahlevi, M., M. Saparudin, S. Maemunah, D. Irma, and M. Ekhsan. 2019. Cybercrime Business Digital in Indonesia. The 4th International Conference on Energy, Environment, Epidemiology and Information System (ICENIS 2019) 125: 1-5.

Fahlevi, Mochammad, A. S. Rabiah, I. A. Pradipta, and A. Marta. 2020. Tourism and Absorption of The Labor Force in Indonesia : A Strategy for Development. The 5th International Conference in Energy, Environmental, and Information System (ICENIS) 202: 2-6.

Foroughi, B., D. Nikbin, S. S. Hyun, dan M. Iranmanesh. 2016. Impact of Core Product Quality on Sport Fans' Emotions and Behavioral Intentions. International Journal of Sports Marketing and Sponsorship 17(2): 110-129. 
Gao, L. and X. Bai. 2014. Online Consumer Behaviour and its Relationship to Website Atmospheric Induced Flow: Insights into Online Travel Agencies in China. Journal of Retailing and Consumer Services 21(4): 653-665.

Gwebu, K. L., J. Wang, and L. Guo. 2014. Continued Usage Intention of Multifunctional Friend Networking Services: a Test of a Dual-Process Model Using Facebook. Decision Support Systems, 67: 66-77.

Hair, J., W. Black, B. Babin, and R. Anderson. 2010. Multivariate Data Analysis: A Global Perspective. Pearson. New Jersey.

Hair, J. F., C. M. Ringle, dan M. Sarstedt. 2011. PLS-SEM : Indeed a Silver Bullet PLS-SEM : Indeed a Silver Bullet. Journal of Marketing Theory and Practice 19(2): 139-152.

Hair, J. F., G. T. M. Hult, C. M. Ringle, and M. Sarstedt. 2017. A Primer on Partial Least Squares Structural Equation Modeling (PLS-SEM) (2nd ed.). Thousand Oaks. Sage.

Horppu, M., O. Kuivalainen, A. Tarkiainen, and H. K. Ellonen. 2008. Online Satisfaction, Trust and Loyalty, and The Impact of The Offline Parent Brand. Journal of Product and Brand Management 17(6): 403-413.

Hussain, S., T. C. Melewar, C. V. Priporas, P. Foroudi, and C. Dennis. 2020. Examining the Effects of Celebrity Trust on Advertising Credibility, Brand Credibility and Corporate Credibility. Journal of Business Research 109: 472-488.

Istan, M. and M. Fahlevi. 2020. The Effect of External and Internal Factors on Financial Performance of Islamic Banking. Jurnal Ekonomi \& Studi Pembangunan 21(72): 137-145.

Jakpat. 2016. What Do Indonesians Seek in Budget Hotel? - Survey Report. https:// blog.jakpat.net/what-do-indonesians-seekin-budget-hotel/.

Juhandi, N., S. Zuhri, M. Fahlevi, R. Noviantoro, M. Nur Abdi, and Setiadi.
2020. Information Technology and Corporate Governance in Fraud Prevention. The 5th International Conference in Energy, Environmental, and Information System (ICENIS), 202.

Kasbuntoro, D. Irma, S. Maemunah, I. Mahfud, M. Fahlevi, and R. D. Parashakti. 2020. Work-Life Balance and Job Satisfaction: A Case Study of Employees on Banking Companies in Jakarta. International Journal of Control and Automation 13(4): 439-451.

Kemenparekraf. 2020. Laporan Kinerja Kementerian Pariwisata Tahun 2019. https://www.kemenparekraf.go.id/asset_ad min/assets/uploads/media/pdf/media_15988 78230_LAKIP_Kemenpar_2019.pdf.

Kim, J., A. M. Fiore, and H.-H. Lee. 2007. Influences of Online Store Perception, Shopping Enjoyment, and Shopping Involvement on Consumer Patronage Behavior towards an Online Retailer. Journal of Retailing and Consumer Services 14(2): 95-107.

Kim, M. J., N. Chung, and C. K. Lee. 2011. The Effect of Perceived Trust on Electronic Commerce: Shopping Online for Tourism Products and Services in South Korea. Tourism Management 32(2): 256265.

Kotler, P. and K. L. Keller. 2016. Marketing Management. Global Edition (Vol. 15E). Pearson Education. New Jersey.

Madan, K. and R. Yadav. 2016. Behavioural Intention to Adopt Mobile Wallet: a Developing Country Perspective. Journal of Indian Business Research 8(3): 227244.

Ngo, V. M. and H. H. Nguyen. 2016. The Relationship between Service Quality, Customer Satisfaction and Customer Loyalty: an Investigation in Vietnamese Retail Banking Sector. Journal of Competitiveness 8(2): 103-116.

Putri, D. W. and Z. Baridwan. 2014. Determinan Kepercayaan Individu: Studi Empiris Konteks. Jurnal Ilmiah Mahasiswa FEB 3(1).

Rabiah, A. S., M. Fahlevi, N. Juhandi, and P. 
Winarto. 2020. Haruskah E-payment Trust Diterapkan E-commerce sebagai Faktor Kepuasan Konsumen? E-Jurnal Manajemen 9(7): 2724-2743.

Ramadan, R. and J. Aita. 2018. A Model of Mobile Payment Usage among Arab Consumers. International Journal of Bank Marketing 36(7): 1213-1234.

Ranganathan, C. and S. Ganapathy. 2002. Key Dimensions of Business-to-Consumer Websites. Information $\mathcal{E}$ management 39(6): 457-465.

Saunders, M., P. Lewis, and A. Thornhill. 2009. Research Methods for Business Students (5th ed.). Harlow. Prentice Hall.

Semeijn, J., A. C. R. van Riel, M. J. H. van Birgelen, and S. Streukens. 2005. Eservices and Offline Fulfilment: How Eloyalty is Created. Managing Service Quality 15(2): 182-194.

Singh, N., S. Srivastava, and N. Sinha. 2017. Consumer Preference and Satisfaction of M-wallets: a Study on North Indian Consumers. International Journal of Bank Marketing 35(6): 944-965.

Slade, E. L., Y. K. Dwivedi, N. C. Piercy, and M. D. Williams. 2015. Modeling Consumers' Adoption Intentions of Remote Mobile Payments in the United Kingdom: Extending UTAUT with Innovativeness, Risk, and Trust. Psychology E Marketing 32(8): 860-873.

Stapleford, T. A. 2017. Econometrics. Modernism and the Social Sciences: AngloAmerican Exchanges, c.1918-1980: 39-76. Cambridge University Press. Cambridge.

Supriadi, O., Z. Musthan, Sa'odah, R. Nurjehan, Y. D. Haryanti, M. Rafid Marwal, A. Purwanto, A. Mufid, R. A. Yulianto, M. Farhan, A. A. Fitri, M. Fahlevi, and S. Sumartiningsih. 2020. Did Transformational, Transactional
Leadership Style and Organizational Learning Influence Innovation Capabilities of School Teachers during Covid-19 Pandemic? Systematic Reviews in Pharmacy 11(9): 299-311.

Sutia, S., S. Adha, and M. Fahlevi. 2019. Why do Customers Intend to Repurchase Transportation Online in Indonesia? The 4th International Conference on Energy, Environment, Epidemiology and Information System (ICENIS 2019) 125: 1-5.

Sutia, S., M. Fahlevi, Rita, A. S. Rabiah, and S. Adha. 2020. The Influence of Endorsement on Instagram toward Customer Behavior. International Journal of Psychosocial Rehabilitation 24(08): 6628-6634.

Suwarni, R. Noviantoro, M. Fahlevi, and M. N. Abdi. 2020. Startup Valuation by Venture Capitalists: an Empirical Study Indonesia Firms. International Journal of Control and Automation 13(2): 785-796.

Syapsan. 2019. The Effect of Service Quality, Innovation towards Competitive Advantages and Sustainable Economic Growth: Marketing Mix Strategy as Mediating Variable. Benchmarking 26(4): 1336-1356.

Weisberg, J., D. Te'eni, and L. Arman. 2011. Past purchase and intention to purchase in e-commerce. Internet Research 21(1): 82-96.

Wicaksono, M. P. A. and N. K. Seminari. 2016. Pengaruh Iklan dan Word of Mouth Terhadap Brand Awareness Traveloka. E-Jurnal Manajemen 5(8): 5098-5127.

Yoon, K. and T. V. Tran. 2011. Revisiting the Relationship between Consumer Loyalty and Price Sensitivity: The Moderating Role of Deal-Proneness. Journal of Marketing Theory and Practice 19(3): 293306. 